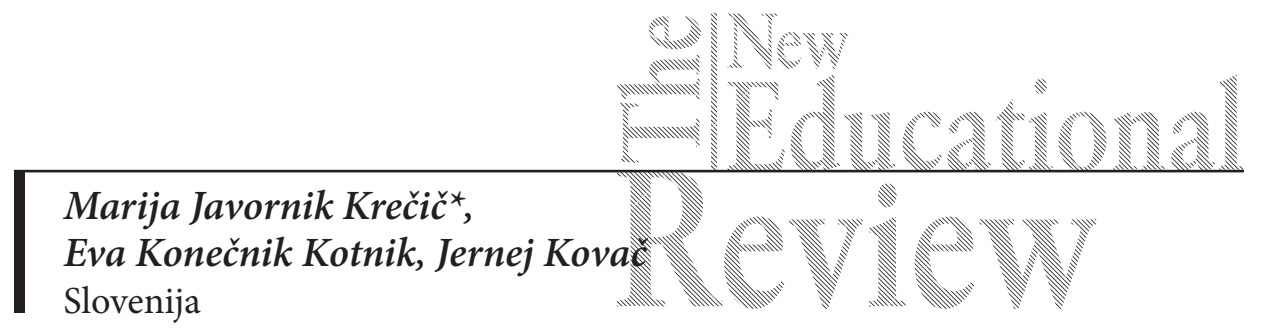

\title{
Process Orientation of the Conception of Student Learning
}

DOI: 10.15804/tner.2015.41.3.16

\begin{abstract}
This article explores the importance of teachers' conceptions of student learning. In the first part, we focus on the teacher conceptions that stimulate process-oriented instruction. In the second part, we present the results of empirical research on teachers in Slovenian border areas. The principal aim of the research was to determine to what extent the teachers' conceptions of student learning are process-oriented (contrary to traditional orientation), and whether there are any differences between teachers who graduated from different faculties and those that were educated in different teacher education programs.
\end{abstract}

Keywords: cognition, teachers' conceptions, conceptions of student learning, teacher education

\section{Introduction}

We live in an era of change (this is evident in all spheres of social life, e.g., rapid advance in knowledge and technology; increasing complexity of life, which demands more knowledge, skills and readiness to control this complexity; movement and interconnection between individuals and nations in different fields; cf., Fullan 1993a, 1993b, 2000, 2001, Peretz, 2004, Černe 2004), because of that the teaching profession is faced with a variety of challenges and uncertainties; these

* Corresponding author. 
demand a higher level of professionalism from teachers and put more emphasis on their professional growth (cf. Lang 1999, Cochran- Smith 2000, Campbell, McNamara \& Gilroy, 2004). Not only are the external signs of the teaching profession and status (e.g., salary, reputation or working conditions) subjected to this; above all, much emphasis is put on the aspect of the teacher's "internal" professional growth/maturation, which gradually leads to more assured decision-making, to self-confidence, as well as to independence of thought and action. The teacher - the "reflective practitioner" (Schön, 1984, 1987) - is not only expected to have command of his/her field and of the different teaching methods and formats, but is also expected to be capable of adapting a wide variety of teaching content, methods and formats to the learning objectives and to the students. It is also important that he/she be able to create a learning environment that enables active learning (Niemi \& Kohonen 1995, Vermut \& Verschaffel, 2000).

The professional growth of the teacher takes place at two levels: the level of conceptions and the level of action (acquisition and improvement of professional skills). Researchers studying the behaviour of teachers and how they were trained stress the importance of knowing what teachers think and what their beliefs are (Pajares, 1992). Within the frame of a cognitive-constructive understanding of teachers' professional development, their behaviour and actions are believed to be closely connected with their individual systems of beliefs, values and principles (Kagan, 1992, Fang, 1996). Trigwell and Prossner (1996) established a statistically significant correlation between conceptions of teaching and approaches towards teaching, and between conceptions of teaching and conceptions of the learning process, as well as a correlation between conceptions of the learning process and approaches towards teaching.

In the presented paper we focus on teachers' conceptions. On the one hand, we offer a theoretical representation of the importance of teachers' "process-oriented" conceptions of student learning. On the other hand, with the help of the results from the empirical research on Slovenian teachers, we illustrate the situation in pedagogical and educational practice.

\section{Theoretical background}

As pointed out by Clark and Peterson (1986), researching teachers' conceptions goes along with researching teachers' cognitions, which represent an integral part of teacher professionalism. One of the main objectives in researching teachers' conceptions is profound teacher self-recognition; as pointed out by Clark and 
Peterson (1986), it is essential to assist teachers on their path from an implicitly directed system of personal expectations to an explicit description of their cognitive reference frame (cf., also Knowles \& Cole, 1996, Mevorach \& Strauss, 2012). This represents the basis for teachers' professional development, and only in this way can teachers progress along with their students (Clark \& Petersen, 1986).

In their research, Bolhuis and Voeten (2004) refer to teachers' conceptions of student learning that stimulate individual learning and therewith process-oriented instruction. One characteristic of "process-oriented teaching" (Vermunt \& Verschaffel, 2000) or "student-oriented teaching" is the stimulation of students' mental activity. Some important aspects of this are as follows: internal regulation of learning, learning as active construction of knowledge, collaborative learning and a dynamic view of intelligence (Bolhuis \& Voeten, 2004: 78). Huber and Roth (1999) also list tolerance of uncertainty among the important aspects, because individuals with a low level of tolerance of uncertainty avoid information that is not consistent with their prior knowledge. Individuals with a high level of tolerance of uncertainty are motivated to learn from completely new situations, as well as from information not consistent with what they already know about a certain subject (Huber \& Sorentino, 1996).

In the remaining sections, we will further elaborate on particular sets of teacher cognitions: regulation of learning, conception of knowledge, conception of learning, conception of abilities and tolerance of conflict and uncertainty

Regulation of Learning. Candy (1991) and Simons (1997) emphasise two aspects important for active learning. The first refers to the extent to which the student is challenged to use most of his/her mental abilities during learning. The concern here is the active use of thinking: whether students are capable of discovering certain things by themselves, and whether they are capable of making certain connections (cf. Schunk \& Zimmerman, 1998). The second aspect, called independent learning by Simons (1997), refers to the self-regulation of learning; students decide about different aspects of the learning process (e.g., the planning of learning activities) as they reflect on their successes and failures. Internally-regulated learning or self-regulated learning (terms used in literature include independent learning, self-regulated, self-directed and self-organized) (Vermut \& Van Rijswik, 1988) is a complex interactive process, characterised by cognitive self-regulation and internal motivation. In the case of external regulation of learning, in contrast the student has little autonomy in his/her learning process.

Why is it important for teachers to perceive learning as a self-regulated process? Research (Pintrich, Marx \& Boyle, 1993, Hofer, Yu \& Pintrich, 1998, Rotgans \& 
Schmidt, 2009) shows that the more challenging the learning (this is especially evident in problem-based learning), and the more mentally and emotionally engaged students have to be, the more prominent the construct of the origin of control becomes. Students who accept internal regulation and believe that they can affect and control their learning process perform better in learning situations and are more involved in solving discrepancies between prior knowledge and new situations.

Conception of knowledge. The teacher's conception of knowledge helps to shape not only his/her conception of learning and of learning methods, but also his/her conception of teaching and teaching strategy. In this way the teacher significantly influences students' conceptions. Active learning is being increasingly emphasized as important (cf., also Hus, Grmek 2010). As noted by various authors (cf., Stern, 1997), there is a higher probability of students understanding and retaining information if they actively use it. Furthermore, it has been proven that students' understanding of knowledge is related to the cognitive processes that take place during the process of learning (cf., Hofer \& Pintrich, 1997). The thesis in Bolhuis and Voeten's (2004) study was that the student's active formation of knowledge is in opposition to the acquisition of knowledge as a unit that can be reproduced.

Conception of learning. In the context of this dimension, Bolhuis and Voeten (2004) state that teachers with a more traditional view are convinced that learning is an individual process, during which students develop individually. Teachers who are more process-oriented emphasise the importance of students learning with others and from others. They are certain that these students achieve better learning outcomes.

Conception of abilities. The teacher's view of knowledge and abilities plays a crucial role in the choice of learning and teaching strategies. Teachers with a dynamic view of knowledge search for abilities; they permit different learning pathways and also create learning pahtways. As stated by Dweck (1988) and Wong (1991) (as cited in Bolhuis \& Voeten, 2004), knowledge is the result of learning by means of experience. In connection with the learning process of the teacher, this aspect can be perceived as the opportunity and potential for (personal) growth and constant learning throughout his/her professional career.

Tolerance of uncertainty. In connection with the internal regulation of learning, one further aspect is important: tolerance of conflict and uncertainty. As the 
results of the research conducted by Huber and Roth $(1999,2003)$ show, teachers with lower thresholds of tolerance for conflict and uncertainty more often use the established methods and strategies to which they are used. However, these teachers do not stimulate individual learning. Furthermore, this aspect is also important because the teacher's professional development cannot be limited only to the development of skills and to the accumulation of knowledge and experience. What is also crucial is personal growth, which means that the teacher develops into a reflective practitioner, characterized by flexibility, the ability to distinguish between emotions, respect for individuality, tolerance of conflict and uncertainty, cultivation of personal relationships and a wider perspective on society (Witherell \& Erickson, 1978; as cited in Zuzovsky, 1990: 4).

To sum up: in the theoretical part of the article we have discussed five aspects of teachers' conceptions / perspectives on student learning. In the remaining part of the article the extent to which these conceptions are process-oriented will be presented - supported by the results of empirical research

\section{Empirical Research}

\section{Research Aims}

We sought to explore the extent to which teachers' conceptions are oriented towards the traditional view or towards the process-oriented view.

Based on factorization (in research by Bolhuis \& Voeten, 2004), there are sets of teacher statements that show their conceptions of student learning. The tables below show the traditional statements on the left, and on the right process-oriented statements by teachers about student learning. These statements were also used in the questionnaire, which featured extreme statements. On the left was the traditional one and on the right the process-oriented one. With each pair of statements, a respondent assessed his/her level of agreement by choosing among the following numerical values:

1 - I totally agree with the statement on the left; 2 - I agree more with the statement on the left than with that on the right; 3 - I agree more with the statement on the right than with that on the left; 4 - I totally agree with the statement on the right.

The results were summed and all statements were considered as one sum. The results were presented in the form of average ranks, where a higher average rank value signifies the teachers' more process-oriented conceptions and a lower value signifies more traditionally oriented conceptions. 
Table 1: Teacher conceptions of regulation of student learning

\begin{tabular}{ll}
\hline $\begin{array}{l}\text { External regulation of learning (traditional } \\
\text { statements): }\end{array}$ & $\begin{array}{l}\text { Internal regulation of learning (process-ori- } \\
\text { ented statment): }\end{array}$ \\
\hline $\begin{array}{l}\text { School is compulsory for students, thus you } \\
\text { can expect motivation problems. }\end{array}$ & $\begin{array}{l}\text { Students lose their motivation in school } \\
\text { if everything is presented in a predigested } \\
\text { way. }\end{array}$ \\
\hline $\begin{array}{l}\text { In general, students are not able to work on } \\
\text { their own. }\end{array}$ & Students are capable of working on their own. \\
\hline $\begin{array}{l}\text { If I do not tell students exactly what to do, } \\
\text { nothing will be achieved. }\end{array}$ & $\begin{array}{l}\text { Students achieve better results when they have } \\
\text { a certain amount of freedom in their work. }\end{array}$ \\
\hline $\begin{array}{l}\text { Learning will be most successful when a teach- } \\
\text { er is in charge of the learning process. }\end{array}$ & $\begin{array}{l}\text { Learning will be most successful when the } \\
\text { students themselves take initiative. }\end{array}$ \\
\hline
\end{tabular}

Table 2: Teachers' conceptions of knowledge

\begin{tabular}{ll}
\hline $\begin{array}{l}\text { Knowledge as reproduction } \\
\text { (traditional statements): }\end{array}$ & $\begin{array}{l}\text { Active construction of knowledge } \\
\text { (process-oriented statment): }\end{array}$ \\
\hline $\begin{array}{l}\text { I can best help students by presenting them } \\
\text { with precisely defined tasks and also telling } \\
\text { them how to solve the tasks. }\end{array}$ & $\begin{array}{l}\text { I let students solve the tasks the way they deem } \\
\text { best. }\end{array}$ \\
\hline $\begin{array}{l}\text { It is important that students learn definitions } \\
\text { by heart. }\end{array}$ & Students have to understand definitions. \\
\hline $\begin{array}{l}\text { It is important that students are informed } \\
\text { about facts and have a precise knowledge of } \\
\text { them. }\end{array}$ & $\begin{array}{l}\text { It is important that students think about } \\
\text { a certain problem and give their own opinions } \\
\text { and views. }\end{array}$ \\
\hline $\begin{array}{l}\text { Mechanical, routine learning is the best way } \\
\text { for students to learn about my subject. }\end{array}$ & $\begin{array}{l}\text { By memorising rules and facts, it is not possi- } \\
\text { ble to learn how to put knowledge to use. }\end{array}$ \\
\hline
\end{tabular}

Table 3: Teachers' conceptions of individual vs. cooperative learning

\begin{tabular}{ll}
\hline $\begin{array}{l}\text { Individual learning } \\
\text { (traditional statements): }\end{array}$ & $\begin{array}{l}\text { Cooperative, group learning } \\
\text { (process-oriented statments): }\end{array}$ \\
\hline $\begin{array}{l}\text { Whenever students work in groups, they usu- } \\
\text { ally learn incorrect things from one another. }\end{array}$ & $\begin{array}{l}\text { Students learn a lot by explaining things to } \\
\text { each other. }\end{array}$ \\
\hline $\begin{array}{l}\text { The efficiency of the method of discussion is } \\
\text { not proportionate to the amount of time it } \\
\text { takes up. }\end{array}$ & $\begin{array}{l}\text { During discussion, students view issues from } \\
\text { different perspectives and viewpoints. }\end{array}$ \\
\hline $\begin{array}{l}\text { Students learn best about the subject when } \\
\text { working individually. }\end{array}$ & $\begin{array}{l}\text { By working in groups, students learn a lot from } \\
\text { each other. }\end{array}$ \\
\hline $\begin{array}{l}\text { Group work interferes with the way the work } \\
\text { in class usually takes place. }\end{array}$ & $\begin{array}{l}\text { Students are more successful if they approach } \\
\text { the subject as a group. }\end{array}$ \\
\hline
\end{tabular}


Table 4: Teachers' conceptions of student ability

\begin{tabular}{ll}
\hline $\begin{array}{l}\text { Non-dynamic conception of abilities } \\
\text { (traditional statements): }\end{array}$ & $\begin{array}{l}\text { Dynamic conception of abilities } \\
\text { (process-oriented statments): }\end{array}$ \\
\hline $\begin{array}{l}\text { From some students I cannot expect any } \\
\text { progress. }\end{array}$ & $\begin{array}{l}\text { Every student is capable of making progress } \\
\text { and becoming more successful. }\end{array}$ \\
\hline $\begin{array}{l}\text { The student's limited abilities are the cause of } \\
\text { his/her lack of success. }\end{array}$ & $\begin{array}{l}\text { It is possible to eliminate the causes of stu- } \\
\text { dents' failures. }\end{array}$ \\
\hline $\begin{array}{l}\text { I cannot change students' personalities during } \\
\text { their education. }\end{array}$ & $\begin{array}{l}\text { It is my task to help students develop their } \\
\text { potential. }\end{array}$ \\
\hline $\begin{array}{l}\text { An unsuccessful student remains unsuccessful } \\
\text { no matter what I do. }\end{array}$ & I can help less successful students. \\
\hline
\end{tabular}

Table 5: Teachers' conceptions of uncertainty

\begin{tabular}{ll}
\hline $\begin{array}{l}\text { Intolerance of uncertainty (traditional state- } \\
\text { ments) }\end{array}$ & $\begin{array}{l}\text { Tolerance of uncertainty (process-oriented } \\
\text { statements) }\end{array}$ \\
\hline $\begin{array}{l}\text { I do not confront students with real-life, } \\
\text { everyday problems because they would not be } \\
\text { able to solve them anyway and they would not } \\
\text { understand them. }\end{array}$ & $\begin{array}{l}\text { It is important to also confront students with } \\
\text { real-life, everyday problems. }\end{array}$ \\
\hline $\begin{array}{l}\text { I only present students with tasks they are able } \\
\text { to comprehend without difficulty. }\end{array}$ & $\begin{array}{l}\text { Students must be allowed to try out different } \\
\text { things. }\end{array}$ \\
\hline $\begin{array}{l}\text { Mistakes and low grades are bad news for } \\
\text { students; thus, students should be protected } \\
\text { from them. }\end{array}$ & $\begin{array}{l}\text { By making mistakes and getting low grades we } \\
\text { learn; I help students with this. }\end{array}$ \\
\hline $\begin{array}{l}\text { There is no point in confronting students with } \\
\text { different views of things. }\end{array}$ & $\begin{array}{l}\text { I present students with different solutions to } \\
\text { a problem, as well as various explanations for } \\
\text { a certain phenomenon. }\end{array}$ \\
\hline
\end{tabular}

We analysed individual sets of conceptions in light of the differences between teachers who completed their studies at different faculties (faculty of arts, faculty of education or academy of education). Such an analysis is grounded in the divi$\operatorname{sion}^{1}$ (contradictory but traditional) of educating teachers either for elementary

1 On the one hand, traditionally, primary school teachers were educated in specialized "mono technical" institutions, which gradually developed from teacher colleges. There, emphasis was put on pedagogical-psychological education, on special didactics, as well as on the educational function - in Slovenia, this was characteristic of academies of education (colleges). Teachers for "elite" secondary schools (general grammar schools) were educated at universities, where they were instructed in the content and methodology of their field and were also trained to conduct research. They received a minimum amount of pedagogical education (what is more, 
schools (SI: ljudska šola) or for "elite" general grammar schools. Despite changes (unification) in education systems, certain traces of this division are still present and cause major difficulties in trying to find more successful models of teacher education. Taking into consideration that this duality also exists in Slovenia, one can expect that because of the different models of teacher education there would be differences between teachers who graduated from different faculties.

\section{Methodology}

\section{Method}

The research was based on descriptive and causal non-experimental methods of empirical pedagogical research (Sagadin, 1993).

\section{Measures}

The questionnaire for the teachers dealt with the teachers' conceptions of student learning. It consisted of two sections. In the introductory section, the purpose of the survey was presented. There were instructions for completion and general questions about the teacher (gender, level of education completed, seniority, title, and post-secondary education completed). The second section included sets of 20 four-level descriptive assessment scales related to the teachers' conceptions of student learning. The scales were inspired by the Bolhuis and Voeten (2004) inventory. The items were translated and adapted to the Slovenian situation. Binary items described two extremes: the traditional conception and the process-oriented perception or attitude of the teacher. The teachers participating in the survey had to estimate which orientation was closer to their beliefs. The statements from the questionnaire are listed in the section Research Aim.

\section{Participants}

While answering the research questions, we used an extensive approach - by using questionnaires we were able to include a large/representative teacher sample. The survey was conducted on a large, simple, random sample of teachers in the

it was usually presented in the form of lectures as was the case with other subjects); it was considered of little value by the professors of the particular discipline. Special didactics was not well established; there was no/limited practical training. This was characteristic of programs for teacher education at faculties of arts and partially at faculties of education, where more emphasis was nevertheless put on pedagogical-didactical contents. Although this disunity no longer exists at a systemic level, many content-related characteristics of this duality remain. 
bilingual areas near the Slovenian-Austrian, Slovenian-Hungarian and Slovenian-Italian borders; in the areas where there is a network of schools with Slovenian minorities, as well as Italian and Hungarian minorities in Slovenia. Questionnaires were sent out to teachers in 118 schools in these areas. 185 teachers responded. The sample comprises $113(58.5 \%)$ teachers who graduated from faculties of education, $27(14.0 \%)$ teachers who graduated from faculties of arts and $45(23.3 \%)$ teachers who graduated from academies of education or other faculties.

\section{Data Analysis}

The data were first analyzed: descriptively expressed scales were described with the following numerical values: 1 - I totally agree with the statement on the left; 2 - I agree more with the statement on the left than with the one on the right; 3 - I agree more with the statement on the right than with the one on the left; 4 - I totally agree with the statement on the right. The results were summed and all statements were considered as one sum. The data were processed with the statistical programme package SPSS, version 12 using the Kruskal-Wallis test for checking differences between groups of teachers.

\section{Results}

The results of the survey are presented the tables below. The results appear in the form of average ranks, where a higher average rank value signifies more process-oriented teacher conceptions and a lower value signifies more traditionally oriented conceptions.

Table 6: Results of the Kruskal-Wallis test of differences in teacher conceptions of student learning according to the faculty from which they graduated.

\begin{tabular}{|c|c|c|c|c|c|}
\hline & Faculty & $\mathbf{n}$ & $\begin{array}{c}\text { Average } \\
\text { rank }\end{array}$ & $c^{2}$ & $\mathbf{P}$ \\
\hline \multirow{3}{*}{$\begin{array}{l}\text { Learning } \\
\text { regulation }\end{array}$} & faculty of education & 113 & 93.49 & \multirow{3}{*}{$c^{2}=0.270$} & \multirow{3}{*}{$\mathrm{P}=0.874$} \\
\hline & faculty of arts & 27 & 88.28 & & \\
\hline & academy of education & 45 & 94.61 & & \\
\hline \multirow{3}{*}{ Knowledge } & faculty of education & 113 & 95.66 & \multirow{3}{*}{$c^{2}=2.821$} & \multirow{3}{*}{$\mathrm{P}=2.44$} \\
\hline & faculty of arts & 27 & 77.37 & & \\
\hline & academy of education & 45 & 95.83 & & \\
\hline
\end{tabular}




\begin{tabular}{|c|c|c|c|c|c|}
\hline & Faculty & $\mathbf{n}$ & $\begin{array}{c}\text { Average } \\
\text { rank }\end{array}$ & $c^{2}$ & $\mathrm{P}$ \\
\hline \multirow{3}{*}{ Group learning } & faculty of education & 113 & 91.38 & \multirow{3}{*}{$c^{2}=3.965$} & \multirow{3}{*}{$\mathrm{P}=0.138$} \\
\hline & faculty of arts & 27 & 80.33 & & \\
\hline & academy of education & 45 & 104.67 & & \\
\hline \multirow{3}{*}{ Abilities } & faculty of education & 113 & 91.38 & \multirow{3}{*}{$c^{2}=3.965$} & \multirow{3}{*}{$\mathrm{P}=0.130$} \\
\hline & faculty of arts & 27 & 80.33 & & \\
\hline & academy of education & 45 & 104.67 & & \\
\hline $\begin{array}{l}\text { Tolerance } \\
\text { of uncertainty }\end{array}$ & faculty of education & 113 & 90.89 & $c^{2}=1.179$ & $\mathrm{P}=0.555$ \\
\hline
\end{tabular}

In none of the thematic sets of teacher conceptions do the results of the Kruskal-Wallis test show any statistically significant differences between the teachers who graduated from different faculties. Nevertheless, from the average ranks we can derive an interesting conclusion (which, of course, is representative only for the presented sample). In the conceptions about the regulation of learning, student knowledge, student abilities, cooperative learning, as well as tolerance of uncertainty, the results show that the teachers who graduated from academies of education are the most process-oriented, whereas the graduates of faculties of arts have the most traditional conceptions. As indicated in the outline of the research, we might look for the reasons in the characteristics of undergraduate teacher education (cf., note 1 ). In the academisation of university undergraduate studies, graduates of faculties of arts do not seem to be capable of developing higher conceptions - owing to the strong disciplinary education in their field of teaching, as well as insufficient professional qualification.

\section{Discussion and Conclusion}

The common finding of the various surveys of students' and teachers' conceptions is that there is a need to recognize these and a need to make opportunities for the reconstruction of these conceptions (e.g., in the organization of the teaching process, in advanced professional training, etc.), and along with these a need to reconstruct teachers' way of acting. Thus, assessment of conceptions is important in several ways: (1) For the teacher (the individual), it is important because it helps him/her to become more aware of his/her conceptions and the conceptions of his/her students. This involves reflection on and planning of pedagogical action and represents a stimulus for the professional development of the individual 
teacher. (2) Assessment of conceptions is also important at the wider research level because it represents a synthesis and generalization of cognition; on the basis of this, adequate conditions for teachers' professional development can be created. According to Gow and Kember $(1993,1994)$, a change in teacher conceptions represents an impetus to change the working context and consequently to achieve better learning outcomes for students.

Finally, we should point out that higher-level teacher conceptions do not automatically ensure better quality teaching; instead, they represent internal criteria for assessing one's work and are an important stimulus towards achieving this standard. The teacher needs help in this endeavor. Help is necessary and important for recognizing/raising awareness about discrepancies between different conceptions, as well as in the search for an individual teaching style, which leads to the integration of conceptions and scientific theories.

\section{References}

Bolhuis, S. M.\& Voeten, J. M. (2004). Teachers' conceptions of student learning and own learning. Teachers and Teaching: theory and practice, 10(1), 77-98.

Clark, C. M. \& Petersen, P. L. (1986). Teachers' Thought Processes. In: Wittrock, M. C. (ed.). Handbook of Research on Teaching. New York: Macmillan Publishing, 255-196.

Campbell, A., O. \& McNamara, P. Gilroy (2004). Practitioner Research and Professional Development in Education. London: Paul Chapman Publishing.

Candy, C. (1991). Self-direction for Lifelong Learning: a comprehensive guide to theory and practice. San Francisco: CA, Jossey-Bass.

- Cochran-Smith, M. (2000). Teacher Education in the Turn of the Century. Journal of Teacher Education, 51(3), 163-165.

Černe, B. (2004). Stalno strokovno spopolnjevanje in šolska prenova. Sodobna pedagogika, 55 (posebna številka), 194-209.

Fang, Z. (1996). A review of research on teacher beliefs and practices. Educational Research, $38,47-65$.

Fullan, M. (1993a). Change Forces. Probing the Depths of Educational Reform. London: The Falmer Press.

Fullan, M. (1993b). Why Teachers Must Become Change Agents. Educational Leadership, 50(6).

Fullan, M. (2000). The return of large - scale reform. Journal of Educational Change, 1, 5-28.

Fullan, M. (2001). The Meaning of Educational Change. New York: Teachers College Press.

Gow, L. \& Kember, D. (1993). Conceptions of teaching and their relationship to student learning. British Journal of Educational Psychology, 63, 20-33. 
Gow, L.\& Kember, D. (1994). Orientations to Teaching and Their Effect on the Quality of Student Learning. Journal of Higher Education. 65(1), 58-74.

Hofer, B. K. \& Pintrich, P. R. (1997). The development of epistemological theories: beliefs about knowledge and knowing and their relation to learning. Review of Educational Research, 67, 88-140.

Hofer, B. K., Yu, S. L. \& Pintrich, P. R. (1998). Teaching college students to be self-regulated learners. In: Schunk, D. H. \& Zimmerman, B. J. (eds.). Self-Regulated Learning; From Teaching to Self-Reflective Practice. New York: The Guildford Press, 57-85.

Huber, G. L. \& Roth, J. H. W. (1999). Finden oder Suchen? Lehren oder Lehren in Zeiten der Ungewissheit. Schwangau: Ingeborg Huber.

Huber, G. L. \& Roth J. H. W. (2003). Active learning from passive teachers? Article presented at $11^{\text {th }}$ ISATT Conference, Leiden (Netherlands).

Huber, G. L. \& Sorentino, R. M. (1996). Uncertainty in interpersonal and intergroup relations: an individual differences perspective. In Sorentino, R. M. \& Higgins, E. T. (ed.). Handbook of Motivation andC: the interpersonal context. New York: Guilford, 591-619.

Hus, V. \& Ivanuš Grmek, M. (2010). Didactic strategies in early science teaching. Educational Studies, 37(2), 159-169.

Kagan, D. M. (1992a). Implications of research on teacher belief. Educational Psychologist, 27, 65-90.

Knowles, G.J. \& A.L. Cole (1996). Developing practice throught field experiences. In: Murray, F.B. (Ed.), The teacher educatior's handbook, San Francisco, CA: Jossey-Bass, 648-688.

Lang, M. (ured.) (1999). Changing Schools, Changing Practices: Perspectives of Educational Reform and Teacher Professionalism. Louvain: IPN Garant Publ.

Mevorach, M. \& S. Strauss (2012). Teacher educators' in-action mental models in different teaching situations. Teachers and Teaching: theory and practice, 18(1), 25-41.

Niemi, H., V. Kohonen (1995). Towards New Professionalism and Active Learning in Teacher Development: Empirical Findings on Teacher Education and Induction. University Tampere.

Pajares, M. F. (1992). Teachers' beliefs and educational research: Cleaning up a messy construct. Review of Educational Research, 62(3), 307-332.

Pintrich, P. R., Marx, R. W. \& Boyle R. A. (1993). Beyond Cold Conceptual Change: The Role of Motivational Beliefs and Classroom Contextual Factors in the Process of Conceptual Change. Review of t Educational Research, 63(2), 167-199.

Rotgans, J. \& Schmidt, H. (2009). Examination of the context-specific nature of self-regulated learning. Educational Studies, 35(3), 239-253.

Schön, D. (1983). The Reflective Practitioner. New York: Basic Books.

Schön, D. (1987). Educating the Reflective Practitioner. San Francisco: Jossey Bass.

Schunk, D. H. \& Zimmerman B. J. (1998). Self-Regulated Learning; From Teaching to Self-Reflective Practice. New York: The Guilford Press

Simons, R. J. (1997). Definitions and Theories of Active Learning. In Stern, D. \& Huber, G. L. Active Learning for Students and Teachers. Report from Eight Countries OECD. Frankfurt am Main: Peter Lang, 19-39. 
Stern, D. (1997). Genesis of study. What are we learning? In Stern, D. \& Huber, G. L. (eds.). Active Learning for Students and Teachers. Report from Eight Countries OECD. Frankfurt am Main: Peter Lang, 13-18, 183-188.

Trigwell, K. \& Prosser, M. (1996). Changing Approaches to Teaching: A Relational Perspective. Studies in Higher Education, 21(3), 275-285.

Vermut, J. \& Van Rijswijk, A. W. (1988). Analysis and Development of Students' Skill in Self-egulated Learning. Higher Education, 17, 647-682.

Vermunt, J. \& Verschaffel, L. (2000). Process-Oriented Teaching. In Simons, R. \& Linden, J. J. T. Duffy (2000). New Learning. Netherlands: Kluwer Academic Publisher, 209-225. Zuzovsky, R. (1990). Professional Development of Teachers: An Approach and its Application in Teacher Training. Article presented at $15^{\text {th }}$ ATEE conference, Limerick (Ireland). 